\title{
The Great Socialist Experiment? The Soviet State in its International Context
}

\section{David L. Hoffmann}

One hundred years ago in wartime Petrograd, American journalist John Reed witnessed the October Revolution. In his classic account, Ten Days that Shook the World, he describes a crowded, smoke-filled hall in Smolny Institute where delegates to the Second Congress of Soviets had gathered. After the Bolshevik seizure of power, Vladimir Lenin mounted the podium to a tremendous ovation and pronounced his famous words: "We shall now proceed to construct the Socialist order!"1 In the shadow of the First World War, the ideals of socialism offered hope for a more just and harmonious society. According to Reed: "On earth [the Russian people] were building a kingdom more bright than any heaven had to offer."2 But the promise of "the Great Socialist Experiment" was never fulfilled. The Soviet system resulted not in a communist utopia but instead in a Stalinist dictatorship, with extreme levels of state intervention and violence.

Lenin's proclamation implied that Soviet state structures would be socialist. But he purposely elided an important fact-never before in history had there been a socialist state, and there was no blueprint of how to construct one. While Bolshevik leaders rejected liberal democracy and called for "all power to the soviets," they had no plan for socialist state building. Instead they drew upon pre-existing state practices-practices of social cataloguing and intervention that had arisen in western Europe during the nineteenth century and had become increasingly coercive during the First World War. Recent scholarship has highlighted similarities between the Soviet Union and other modern states. Scholars have shown, for example, that Russian and Soviet ethnographers' tabulation of ethnic groups was a part of an international trend toward using population statistics as a tool of government. ${ }^{3}$ Another scholar has demonstrated that interventionist features of Soviet rule, including surveillance and grain requisitioning, had been practiced by governments across Europe during the First World War. ${ }^{4}$ Other studies have compared Soviet population management with parallel efforts in a range of twentieth-century states. ${ }^{5}$ Soviet methods of rule, then, were not uniquely "socialist" and instead reflected modern forms of governance.

1. John Reed, Ten Days that Shook the World (New York, 1967), 129.

2. Reed, Ten Days, 230.

3. Francine Hirsch, Empire of Nations: Ethnographic Knowledge and the Making of the Soviet Union (Ithaca, 2005); Juliette Cadiot, "Le laboratoire impérial: Russie-URSS 18701940” (PhD diss., Centre National de la Recherche Scientifique, 2007).

4. Peter Holquist, Making War, Forging Revolution: Russia's Continuum of Crisis, 19141921 (Cambridge, Mass., 2002).

5. Amir Weiner, ed., Landscaping the Human Garden: Twentieth-Century Population Management in a Comparative Framework (Stanford, 2003). See also David L. Hoffmann and Yanni Kotsonis, eds., Russian Modernity: Politics, Knowledge, Practices (New York, 2000); Stephen Kotkin, "Modern Times: The Soviet Union and the Interwar Conjuncture," Kritika 2, no. 1 (Winter, 2001): 111-64; Daniel Beer, Renovating Russia: The Human 
At the same time, the Soviet Union clearly did not fit the western European model of nation-states, parliamentary democracy, and industrial capitalism (an idealized model to which western European countries themselves did not fully conform). How, then, are we to classify the Soviet system? Recent theorists have introduced the concept of "multiple modernities"-an approach that, while acknowledging commonalities, allows for divergent trajectories of development in the modern era. ${ }^{6}$ By examining the Soviet system within this framework, we are able to recognize it as one particular incarnation of modern state practices. The particularities of the Soviet state reflected not only Marxist-Leninist ideology but also the nurturist orientation of Russian disciplinary culture, something which accounts for many Russian intellectuals' embrace of Marxism in the first place. Also crucial was the Soviet state's formation at a moment of total war-the juncture of the First World War and Civil War-when wartime practices became institutionalized as building blocks of the new Soviet order.

\section{State Interventionism}

If Bolshevik leaders did not invent the forms of state intervention they used, then where did these methods originate? Since ancient times, rulers had acted upon those they ruled, taxing subjects, enslaving conquered peoples, executing political foes. But efforts to refashion populations began only in the early modern era, and these attempts were predicated on a conception of society as an artifact that could be studied and transformed. Seventeenth-century cameralist thinkers were the first to analyze state military power as a product of the population's economic capacity. They advocated a state role in fostering a productive society, which would create wealth and increase tax revenues. The ambition to refashion society subsequently expanded with the eighteenthcentury French Enlightenment. The idea of radically restructuring society had been inconceivable within a traditional worldview that saw God as the sole arbiter of human affairs. But Enlightenment thinkers perceived the social world as neither divinely preordained nor fixed but rather of humankind's own making. They raised the possibility of directed social change and envisioned a "science of society" as the basis of a rational social order. ${ }^{7}$

The French Revolution in turn proved that the existing social and political order could be transformed. The Revolution thus marked not only the overthrow of the old regime but a radical break with conventional notions

Sciences and the Fate of Liberal Modernity, 1880-1930 (Ithaca, 2008); Yanni Kotsonis, States of Obligation: Taxes and Citizenship in the Russian Empire and Early Soviet Republic (Toronto, 2014).

6. S. N. Eisenstadt, "Multiple Modernities," in his Multiple Modernities, ed. S. N. Eisenstadt (New Brunswick, 2002). For work that applies this concept to Russian history, see S. A. Smith, Revolution and the People in Russia and China: A Comparative History (Cambridge, 2008), 5-6; Michael David-Fox, "Multiple Modernities vs. Neo-Traditionalism: On Ongoing Debates in Russian and Soviet History," in Michael David-Fox, Crossing Borders: Modernity, Ideology, and Culture in Russia and the Soviet Union (Pittsburgh, 2015).

7. Keith Michael Baker, “A Foucauldian French Revolution?” in Jan Goldstein, ed., Foucault and the Writing of History (Cambridge, Mass., 1994), 195-96. 
about the social order and the possibility of remaking it. Following the French Revolution, the social sciences gained prominence throughout western Europe. The overthrow of the French monarchy undermined traditional conceptions of political power and enabled new forms of authority to emerge. Social sciences provided a model of science deemed applicable to human affairs, and also delineated a social field, whereby societies were seen as entities that could be mapped statistically and reordered. Demography, sociology, and social statistics made problems legible and heightened reformers' ambitions to eliminate poverty and disease.

In the twentieth century, state actors increasingly took over social regulation, partly due to national security concerns. The rise of mass warfare meant that national defense required a large and able-bodied population. During the First World War, government leaders across Europe sought to manage health and reproduction so as to safeguard their countries' "military manpower." To protect national security, they also took coercive steps including censorship, surveillance, deportations, and the internment of "enemy aliens." In Russia, too, wartime mobilizations, widespread epidemics, and security measures prompted greater state control. Government initiatives included public health measures and refugee relief, as well as the deportation of ethnic and religious minorities from the front. ${ }^{8}$ Following the downfall of the tsarist autocracy, the Provisional Government continued to expand the role of the state. It established ministries of health, state welfare, and food supply, and it also increased government coercion, for example using military force to requisition grain. ${ }^{9}$

When the Bolsheviks took power in October, they continued these practices of social intervention, through the Commissariat of Health, the Commissariat of Welfare, state control of factories, and grain requisitioning. State management of public health provides an illustrative example. Commissariat of Health officials viewed the population's health as a state concern and abolished private medicine in favor of a state-run system. Indeed, Soviet socialized medicine might appear to be the product of socialist ideology. Yet Lenin and other Bolshevik leaders did not have well-developed ideas about health care. The proposal for a government ministry of health had first been approved by Nicholas II in late 1916, and then enacted by leaders of the Provisional Government. Most of the work organizing the Soviet health care system fell to non-Party physicians who themselves believed in principles of social medicine-free, universal health care, with an emphasis on hygiene and disease prevention. ${ }^{10}$

When we place the Soviet health system in its international context, we see similar developments in other countries as well. With the rise of epidemiology, public health experts throughout Europe had also moved away

8. See Peter Gatrell, A Whole Empire Walking: Refugees in Russia during World War I (Bloomington, 1999); Joshua A. Sanborn, Imperial Apocalypse: The Great War and the Destruction of the Russian Empire (Oxford, 2014).

9. Holquist, Making War, Forging Revolution, 109-11.

10. Gosudarstvennii Arkhiv Rossiiskoi Federatsiia (GARF), fond (f). A-482 (Narkomzdrav RSFSR), opis' (op.) 1, delo (d.) 1, list (1.) 33; John F. Hutchinson, Politics and Public Health in Revolutionary Russia, 1890-1918 (Baltimore, 1990), 185-202. 
from individualist approaches in favor of state-administered preventative medicine. In the wake of the First World War, governments around the world established ministries of health. Not only had the war proven the need to protect the bodily health of the population, but widespread epidemic diseases required broad-based state action. Soviet health care reflected international trends-the rise of social medicine and the dramatic expansion of the state's role as guarantor of public health.

The Soviet system, then, is best contextualized within more general trends toward state interventionism. Throughout Europe, and in countries around the world, expert interventions and state management of society developed with the rise of social science and modern medicine, and emerged full-blown in the twentieth century. During the First World War, political leaders of all combatant countries sought to mobilize populations and resources as never before, through propaganda campaigns, public health and welfare measures, economic controls, and, in the case of groups deemed dangerous, forced deportations and internment camps. Soviet forms of social intervention mirrored these trends; the Bolsheviks adopted pre-existing state practices as their means of governance.

\section{Population Management}

To point out the international trend toward state interventionism is not to deny distinguishing features of Soviet policies. While government officials in many countries intervened to manage their populations, their goals varied considerably. To take the case of Soviet reproductive policies, we see that the Soviet government sought to raise the birthrate but strongly rejected eugenics. Soviet pronatalism also resulted in a distinctive construction of gender, emphasizing women's roles as both mothers and workers. Population management took on different forms when instituted in different political and ideological contexts. ${ }^{11}$

Prior to the modern era, reproduction had been considered a natural phenomenon, not something that could be controlled by the state. But nineteenthcentury censuses made it possible for officials to chart population trends and seek to influence them. In the twentieth-century, the First World War required nations to field vast numbers of soldiers, but it simultaneously decimated their ranks, making population concerns even more urgent. During the interwar period, European political leaders sought to replenish their populations, but the loss of young men during the war reduced the number of potential fathers so much that birthrates plummeted. In response, governments introduced propaganda campaigns, birth bonuses, tax incentives, and restrictions on abortion to increase fertility.

Soviet leaders faced similar challenges following the First World War and Civil War, which (along with famines and epidemics) left 16 million

11. On "Russian particularism in the face of universalism," see Susan Gross Solomon, "Circulation of Knowledge and the Russian Locale," Kritika: Explorations in Russian and Eurasian History 9, no. 1 (Winter 2008): 9-26, here 21. 
people dead..$^{12}$ Because of the country's largely peasant population, its birthrate remained high in the 1920s, but fertility dropped precipitously during industrialization, collectivization, and the 1932-33 famine..$^{13}$ A 1934 demographic study showed that the Soviet birthrate overall had fallen from 42.2 births per thousand people in 1928 to 31.0 in 1932, largely due to urbanization and increasing numbers of women in the industrial workforce. ${ }^{14}$ The Soviet government responded with pronatalist propaganda, monetary rewards to women with seven or more children, and the outlawing of abortion in $1936 . .^{15}$

Pronatalist propaganda in the Soviet Union and other countries presented having children as women's "natural role"-an essentialist view of women as mothers. But despite this similarity, the Soviet construction of gender differed in that it also depicted women as workers. The Soviet government expected women to continue working while pregnant and after giving birth. In 1936, the Politburo made it a criminal offense to refuse to hire or to lower the pay of women during pregnancy. ${ }^{16}$ And Soviet propaganda stressed women's roles as both workers and mothers, denying there was any contradiction between the two. Officials in western Europe, on the other hand, blamed women's employment for the decline in the birthrate and urged women to stay home and have children. ${ }^{17}$

Soviet reproductive policies diverged with regard to eugenics as well. Alongside efforts to raise overall birthrates, Scandinavian countries, Nazi Germany, and several states in the US took anti-natalist measures to restrict reproduction among "unfit" members of society. By contrast, the Soviet government sought to increase the birthrate among all segments of the population and in the late 1930s vehemently rejected eugenics as a fascist science. ${ }^{18}$ Despite some initial interest in eugenics by Soviet scientists, anti-natalist thought never took root in the Soviet Union. Soviet physicians emphasized people's living environment and reproductive health rather than sterilizations as the means to effect a biosocial transformation. ${ }^{19}$ Russian social sciences and medicine had arisen in the context of an underdeveloped society ruled by a despotic tsarist bureaucracy. Because the intelligentsia had blamed the population's downtrodden condition on the autocracy rather than on the

12. Frank Lorimer, The Population of the Soviet Union: History and Prospects (Geneva, 1946), 40-41.

13. Rossiiskii gosudarstvennyi arkhiv ekonomiki (RGAE) f. 1562 s. ch. (Tsentral'noe statisticheskoe upravlenie, sekretnaia chast'), op. 329, d. 21, 1. 109.

14. S. G. Strumilin, "K problem rozhdaemosti v rabochei srede," in S. G. Stumilin, Problemy ekonomiki truda (Moscow, 1957), 194-98.

15. Sobranie zakonov i rasporiazhenii raboche-krest'ianskogo pravitel'stva Soiuza Sovetskikh Sotsialisticheskikh Respublik, no. 34 (July 21, 1936), 510-11.

16. Rossiiskoi Gosudarstvennii Arkhiv Sotsial'no - Politicheskoi Istorii (RGASPI) f. 17 (Tsentral'nyi komitet VKP(b)), op. 3, d. 981, 1. 69.

17. Karen Offen, "Body Politics: Women, Work and the Politics of Motherhood in France, 1900-1950," in Gisela Bock and Pat Thane, eds., Maternity and Gender Policies: Women and the Rise of the European Welfare State, 1880s-1950s, ed. (London, 1991), 138.

18. Mark Adams, "Eugenics in Russia, 1900-1940: Toward a Comparative History of Eugenics," in Mark Adams, ed., The Wellborn Science: Eugenics in Germany, France, Brazil, and Russia (New York, 1989), 196.

19. Frances Lee Bernstein, The Dictatorship of Sex: Lifestyle Advice for the Soviet Masses (DeKalb, 2007), 173. 
people themselves, Russian disciplinary culture emphasized the role of the environment over genetics. Russian professionals never accepted the inferiority of the masses as immutable and pursued social improvement through maternal welfare rather than through negative eugenics. The nurturism of Russian disciplinary culture in fact subsequently meshed well with Marxism, given its emphasis on environmental factors in the transformation of human consciousness.

In its condemnation of population management based on genetic determinism, the Soviet Union was similar to other late-developing countries. In Japan, China, Iran, Turkey, and most Latin American nations, officials and physicians rejected negative eugenics in favor of measures to improve hygiene and reproductive health. ${ }^{20}$ In fact, while Soviet authorities borrowed many ideas about population management from western Europe, the Soviet case more closely resembled that of non-European countries. Professionals in late-developing nations shared a sense of inferiority and shame at their populations' high rates of illiteracy, infectious diseases, and infant mortality. They saw science and modern medicine as means to uplift the masses. In the absence of strong civic organizations, they relied on state interventions to achieve social amelioration. And drawing on a pre-existing critique of capitalist industrialization, they sought to avoid the pitfalls of western modernity, even as they pursued modernization. Compared to many western European programs, Soviet population management had distinctive features-a construction of gender that emphasized women's roles as mothers and workers, and a strong rejection of eugenics. But placed in a global context, the Soviet case clearly had significant parallels with other late-developing countries. ${ }^{21}$

\section{State Violence}

If Soviet population management paralleled international trends, then why did it include such extreme state violence? Why did the security police deport and incarcerate people on a massive scale? By 1940, the Soviet government had imprisoned nearly two million people in Gulag labor camps, and that figure does not even include over one and a half million "kulaks" sent to special settlements during collectivization. ${ }^{22}$ Party leaders did not invent concentration camps, so it is important to consider how this form of state violence originated and why it became so central to the Soviet system. Also significant

20. Nancy Leys Stepan, “The Hour of Eugenics”: Race, Gender, and Nation in Latin America (Ithaca, 1991). On Romania, see: Maria Bucur, Eugenics and Modernization in Interwar Romania (Pittsburgh, 2002).

21. See also Adeeb Khalid, "Backwardness and the Quest for Civilization: Early Soviet Central Asia in Comparative Perspective," and Adrienne Edgar, "Bolshevism, Patriarchy, and the Nation: The Soviet 'Emancipation' of Muslim Women in Pan-Islamic Perspective," Slavic Review 65, no. 2 (Summer 2006): 231-251 and 252-272, respectively.

22. Nicolas Werth, "A State against its People: Violence, Repression, and Terror in the Soviet Union," in Stéphane Courtois and Mark Kramer, eds., The Black Book of Communism: Crimes, Terror, Repression (Cambridge, Mass., 1999), 190-91, 213. 
in this regard were the functions attached to concentration camps by Soviet authorities.

State violence was not new to the modern era. In Russia the tsarist government had a long tradition of exiling individual criminals and political prisoners, dating from the seventeenth century. Only in the nineteenth century, however, did officials in imperial Russia use the new discipline of "military statistics" to categorize ethnic groups according to their political reliability. During the First World War, these categories served as the basis for tsarist state violence-massive deportations and internments of entire units of the population. ${ }^{23}$ For other European powers, overseas empires served as the arena where administrators developed systems of social cataloguing to control colonial populations. And it was in the context of colonial warfare that European rulers invented concentration camps. In 1896, just prior to the Spanish-American War, the Spanish military governor of Cuba sought to suppress a revolt by imprisoning segments of the civilian population, and four years later, British generals established concentration camps to imprison civilians in the Boer War. ${ }^{24}$

During the First World War, governments set up concentration camps within Europe itself. Britain, France, and Germany all created internment camps that held tens of thousands of "enemy aliens"-non-naturalized foreigners from combatant countries. ${ }^{25}$ In multi-national empires, rulers engaged in similar practices toward their own subjects who were members of national and religious minorities they did not trust. The Austro-Hungarian government interned Ruthenians and, after Italy entered the war, at least 75,000 Italian subjects. ${ }^{26}$ The tsarist government deported all adult male ethnic Germans from the Polish provinces of the Russian empire in December 1914, and the following month expelled "all Jews and suspect individuals" from the front region. Beginning in January 1915, Russian authorities in the Caucasus deported 10,000 of their Muslim subjects, including over 5,000 to an internment camp established on an uninhabited island in the Caspian Sea. ${ }^{27}$

Following the October Revolution, the Bolsheviks used concentration camps to imprison civilians during the Civil War. Rather than targeting religious and national minorities, they incarcerated class enemies-a different type of social cataloguing based on class rather than ethnicity. In 1922, the Soviet government established a large labor camp complex on the Solovetskii islands in the White Sea, and this camp became a model for the

23. Holquist, Making War, Forging Revolution, 175.

24. Isabel Hull, Absolute Destruction: Military Culture and the Practices of War in Imperial Germany (Ithaca, 2005), 73.

25. Panikos Panayi, The Enemy in Our Midst: Germans in Britain during the First World War (New York, 1991); Jean-Claude Farcy, Les camps de concentration Francais de la Première Guerre mondiale (Paris, 1995); Eric Lohr, Nationalizing the Russian Empire: The Campaign against Enemy Aliens during World War I (Cambridge, Mass., 2003), 178.

26. Holger H. Herwig, The First World War: Germany and Austria-Hungary 1914-1918 (New York, 1997), 127, 160.

27. Lohr, Nationalizing the Russian Empire, 130-39, 151-52; Sanborn, Imperial Apocalypse, 119-21. 
entire Gulag system. ${ }^{28}$ Labor camps, like internment camps, isolated those deemed dangerous, but they also forced inmates to perform hard labor. Soviet theorists touted labor as a means to re-educate criminals and class enemies, and some scholars have emphasized the redemptive function camps were intended to play. ${ }^{29}$ Other scholars have focused instead on the Soviet government's use of labor camps to exploit prisoners for the sake of the industrialization drive. ${ }^{30}$

In either case, we see concentration camps-a form of state violence from colonial warfare and the First World War-retaining a similar form but gaining new functions. Whereas previously governments had used concentration camps during wartime, Soviet authorities employed concentration camps during peacetime, and they did so not just to contain perceived threats but to develop the economy and reshape society. At the end of the First World War, other combatant countries stepped back from wartime practices. By contrast, the Soviet state was born at this moment of total war, and it institutionalized concentration camps, surveillance, censorship, and coercion as permanent features of governance. ${ }^{31}$ Ideological goals could be attached to wartime practices. But rather than conclude that state violence emanated from ideology, we see that pre-existing practices of state violence were ideologized, that is they were wielded to ideological goals of social transformation.

Collectivization provides a clear example of wartime practices deployed for ideological aims. ${ }^{32}$ State-run collective farms served both to eliminate capitalist agriculture and to secure state control over grain production. But the decision by Joseph Stalin and his fellow leaders to collectivize agriculture does not explain how they proceeded with collectivization. They could have used penalties and incentives to induce peasants to join collective farms. Instead they launched a military-style campaign that sought to remove class enemies ("kulaks") from the village. Using a system of social cataloguing, Soviet leaders ordered that first-category kulaks (those considered "counterrevolutionary activists") be sent to the Gulag or executed, and some 30,000 were shot. Second-category kulaks, between 1.6 and 1.8 million people, were dispossessed and deported to "the unknown Gulag"-special settlements where

28. Oleg Khlevniuk, The History of the Gulag: From Collectivization to the Great Terror (New Haven, 2004), 9; Werth, “A State against its People," 136-38.

29. Iosif L. Averbakh and Andrei Vyshinsky, Ot prestupleniia k trudu (Moscow, 1936), 24; Steven A. Barnes, Death and Redemption: The Gulag and the Shaping of Soviet Society (Princeton, 2011).

30. See, for example, Paul R. Gregory and Valery Lazarev, eds., The Economics of Forced Labor: The Soviet Gulag (Stanford, 2003); Golfo Alexopoulos, "Destructive-Labor Camps: Rethinking Solzhenitsyn's Play on Words," Kritika: Explorations in Russian and Eurasian History 16, no. 3 (June 2015): 499-526.

31. On surveillance, see Holquist, Making War, Forging Revolution, 238-40; on censorship, see A. V. Blium, Za kulisami “Ministerstva pravdy": Tainaia istoriia sovetskoi tsenzury: 1917-1929 gg. (St. Petersburg, 1994), 32-39; and on coercion, see Donald Raleigh, Experiencing Russia's Civil War: Politics, Society, and Revolutionary Culture in Saratov, 1917-1922 (Princeton, 2002), 308-11.

32. For other examples of Soviet social cataloguing and state violence, see David R. Shearer, Policing Stalin's Socialism: Repression and Social Order in the Soviet Union, 19241953 (New Haven, 2009). 
deportees were isolated from the population and subjected to forced labor. ${ }^{33}$ The Stalinist regime thus used wartime practices of mass deportations and incarcerations to transform the socio-economic order in the countryside. ${ }^{34}$

For both its admirers and detractors, the October Revolution quickly became a symbol of socialism. Fellow leftists joined John Reed in his enthusiasm for "the Great Socialist Experiment." 35 Those on the right condemned the Revolution and, even today, blame socialist ideology for Soviet state violence. ${ }^{36}$ But when we place the Soviet state in its international context, we see that many of its features reflected more general practices of population management and social intervention.

Such is not to argue that the Soviet state was simply an extension of international trends. The Soviet system is better conceptualized as one particular incarnation of modern state practices-practices of social intervention that arose in nineteenth-century Europe and subsequently informed reform programs throughout the world. Like their counterparts in other late-developing countries, Soviet professionals used state power to modernize their society, even as they sought to avoid the ills of capitalist modernity. The nurturist and statist orientation of Russian disciplinary culture meshed well with official Marxist ideology and the state-run economy. What also distinguished the Soviet state was its institutionalization of wartime practices as permanent features of governance. With no legal constraints on their authority, Stalin and his fellow leaders deployed these practices of state violence in their ruthless drive to transform the country.

The Soviet state in turn exerted enormous influence on international developments. For the entirety of its existence, the Soviet Union offered an alternative model to that of liberal democracy and free-market capitalism. The Soviet planned economy, originally patterned on German World War I planning, attracted the attention of economists worldwide including Rexford Tugwell, a member of Franklin Roosevelt's New Deal brain trust. In the postwar era, leaders of many developing nations were drawn to the Soviet model as a vehicle for economic and social advancement. The state-run economy seemed to mobilize human and natural resources effectively, while avoiding the class antagonisms of capitalist industrialization. Soviet leaders had rapidly modernized a largely peasant society plagued by poverty and backwardness. From the depths of military humiliation and chaos at time of the October

33. Lynne Viola, The Unknown Gulag: The Lost World of Stalin's Special Settlements (New York, 2007), 22-23.

34. My focus on practices of state violence is not intended to exonerate Stalin and his fellow leaders for the deportations, incarcerations, and executions they ordered. Social cataloguing, a security police apparatus, and concentration camps were conceptual and practical preconditions of Soviet state violence, not direct causes. For further discussion, see David L. Hoffmann, Cultivating the Masses: Modern State Practices and Soviet Socialism, 1914-1939 (Ithaca, 2011), 303-5.

35. See, for example, John Dewey, "The Great Experiment and the Future," in John Dewey, Impressions of Soviet Russia and the Revolutionary World, Mexico, China, Turkey (New York, 1929).

36. Stéphane Courtois, “Conclusion: Why?” in Courtois and Kramer, eds., The Black Book of Communism, 737. 
Revolution, the Soviet state had become a superpower, capable of defeating Nazi Germany and rivaling the United States for world domination. But to accomplish this transformation, Soviet leaders had inflicted horrendous casualties and human suffering. In the end, their violent methods served to discredit the Soviet system, as well as the socialist ideals it was supposed to exemplify. 